\title{
STANOWISKO PARLAMENTU EUROPEJSKIEGO WOBEC PROBLEMU PROLIFERACJI BRONI MASOWEGO RAŻENIA I TERRORYZMU MIĘDZYNARODOWEGO
}

Celem artykułu jest analiza stanowiska Parlamentu Europejskiego (PE) wobec kluczowych zagrożeń dla bezpieczeństwa UE, a zwłaszcza problemu proliferacji broni masowego rażenia i zjawiska terroryzmu międzynarodowego. Należy podkreślić, że PE jest jedyną mającą demokratyczną legitymację instytucją unijną reprezentująca społeczeństwa Europy. Oznacza to, że PE w swojej działalności może powoływać się na wolę europejskiej opinii publicznej, zarazem ją kształtując dzięki posiadaniu szerokiego spektrum instrumentów oddziaływania (debaty parlamentarne, rezolucje, raporty, zalecenia). Pozwala mu to wpływać poza zakresem swoich traktatowych kompetencji na decyzje Rady UE będącej głównym organem kształtującym politykę bezpieczeństwa UE (Staszczyk, 2015: 230). Z tego względu, zamierzeniem nie jest analiza kompetencji decyzyjnych PE w obszarze tej polityki zdominowanej przez mechanizmy współpracy międzyrządowej, ale weryfikacja hipotezy, w myśl której PE jako instytucja ponadnarodowa nieposiadająca realnych uprawnień władczych w odniesieniu do Wspólnej Polityki Bezpieczeństwa i Obrony (WPBiO), ale pelniąca w obszarze tej polityki jedynie rolę organu doradczo-konsultacyjnego i opiniodawczego jest jednak kluczową instytucją wpływu politycznego w procesie kształtowania unijnej polityki wobec problemu rozprzestrzeniania broni masowego rażenia i występowania zagrożeń terrorystycznych. Podstawowym instrumentem wpływu są uchwalane przez ten organ rezolucje. Są to najliczniejsze dokumenty posiedzeń plenarnych Parlamentu, które dzielą się na prawodawcze (dotyczące projektów legislacyjnych) oraz nielegislacyjne - wszystkie pozostałe (Ogonowska, 2006: 18). PE próbuje wpływać na kształt i kierunki rozwoju polityki UE wobec priorytetowych zagrożeń przede wszystkim poprzez przyjmowanie rezolucji nielegislacyjnych. Dokumenty te - mimo że nie stanowią elementu procesu decyzyjnego i pozbawione są mocy prawnej - pozwalają temu organowi wyrazić swoje stanowisko wobec tych kwestii, jak i pośrednio wpływać na kształtowanie podejścia UE wobec tych zagrożeń. Z uwagi na to, że funkcjonowanie UE cechuje się wysokim poziomem instytucjonalizacji, a kluczowym wyzwaniem badawczym w niniejszym artykule jest analiza tekstów rezolucji przyjmowanych przez PE, niezbędne stało się zastosowanie metody analizy instytucjonalno-prawnej (por. Chodubski, 2012: 25). Jej zastosowanie pozwala na poznanie opinii PE w kwestii przeciwdziałania kluczowym zagrożeniom dla bezpieczeństwa europejskiego oraz udzielenie odpowiedzi na pytanie jaka jest preferowana przez PE koncepcja podejścia UE w dziedzinie zwalczania terroryzmu i przeciwdziałania proliferacji broni masowego rażenia. 
Zbiór wyzwań i zagrożeń stojących przed UE został wyartykułowany w przyjętej przez Radę Europejską (RE) w grudniu 2003 r. Europejskiej Strategii Bezpieczeństwa (dalej: ESB). Powstanie tego dokumentu było konsekwencją dostrzeżenia przez jednoczącą się Europę nowych asymetrycznych wymiarów bezpieczeństwa. W przyjętym stanowisku PE z zadowoleniem przyjął zawarte w tym dokumencie całościowe podejście do pojęcia bezpieczeństwa. Mając na uwadze, że ESB jest częścią Wspólnej Polityki Zagranicznej i Bezpieczeństwa (dalej: WPZiB) i WPBiO, w ramach których można zastosować całe spektrum działań politycznych UE obejmujących środki dyplomatyczne, ekonomiczne i polityki rozwojowej, PE podzielił pogląd RE, że najważniejsze zagrożenia dla światowego bezpieczeństwa to terroryzm, rozprzestrzenianie broni masowego rażenia, nierozwiązane konflikty regionalne, upadłe i upadające państwa oraz przestępczość zorganizowana. Podkreślił zarazem, że stosowanie środków militarnych w celu eliminacji tych zagrożeń jest ostatecznością. W opinii PE najlepiej zapewnieniu bezpieczeństwa na świecie będzie służyć połączenie różnych potencjałów, programów i instrumentów pomocowych, będących w dyspozycji UE i jej członków (Rezolucja, 2006a).

\section{PE WOBEC PROBLEMU ROZPRZESTRZENIANIA BRONI MASOWEGO RAŻENIA}

Analizując stanowisko PE wobec problemu rozprzestrzeniania broni masowego rażenia (BMR) w kontekście funkcjonowania WPBiO należy uwzględnić zapisy ESB, według której problem ten stanowi potencjalnie najpoważniejsze zagrożenie dla bezpieczeństwa europejskiego, do którego UE przywiązuje najwyższą wagę. Zagrożenie to ma tendencję rosnącą, gdyż obszarami szczególnie podatnymi na proliferację BMR są ogarnięte konfliktami Bliski Wschód i Azja. Sytuacja ta rodzi ryzyko faktycznego użycia tej broni w konfliktach występujących na tych obszarach, a także potęguje możliwość wyprodukowania i wykorzystania BMR przez terrorystów. W opinii UE system nieproliferacji BMR, aby był skuteczny musi opierać się na wprowadzaniu w życie odpowiednich traktatów i umów międzynarodowych, skutecznym rozwiązywaniu kryzysów związanych z proliferacją oraz ścisłej współpracy operacyjnej w jej zwalczaniu. Kluczową kwestią dla bezpieczeństwa europejskiego jest według UE zapobieganie procederowi proliferacji poprzez przeciwdziałanie transferom wiedzy, technologii, towarów, sprzętu oraz zwalczanie finansowania rozprzestrzeniania BMR i karanie za akty proliferacji. Polityka UE w kwestii proliferacji BMR opiera się przede wszystkim na wiedzy i przewidywaniu (analiza oceny ryzyka i zagrożenia), zapobieganiu, utrudnianiu i powstrzymywaniu, współpracy i udzielaniu wsparcia w dziedzinie rozprzestrzeniania BMR, koordynacji działań (Nowe, 2008). Należy podkreślić, że jej kluczowe znaczenie dla bezpieczeństwa europejskiego wynika z faktu, że wszystkie państwa UE są stronami najważniejszych porozumień wielostronnych, które tworzą system nierozprzestrzeniania BMR. Porozumienia te to: układ o nierozprzestrzenianiu broni jądrowej (NPT) z 1968 r., Konwencja o zakazie sprowadzania, badań, produkcji i gromadzenia zapasów broni bakteriologicznej (biologicznej) i toksycznej oraz ich zniszczeniu (BTWC) z 1972 r., Konwencja o zakazie prowadzenia badań, produkcji, 
gromadzenia i użycia broni chemicznej oraz jej niszczeniu (CWC) z 1993 r., a także Traktat o zakazie przeprowadzania prób nuklearnych (CTBC) z 1996 roku. Wszystkie te porozumienia wpisują się w prowadzony już w okresie zimnej wojny i kontynuowany do dnia dzisiejszego dialog rozbrojeniowy, którego efektem było między innymi podpisanie układu START (ang. Strategic Arms Reduction Treaty) I i II. Dialog ten nie przebiegał bezproblemowo, gdyż Rosja nie ratyfikowała ostatecznie układu START II, a USA podjęły jednostronną decyzję o wycofaniu się z układu o ograniczeniu systemów obrony przeciwrakietowej ABM (ang. Anti-Balistic Missile), który stanowił przeszkodę w realizacji projektu budowy tarczy antyrakietowej mającej chronić USA i jej sojuszników przed atakiem nuklearnym państw określanych jako „bandyckie” (Korea Północna, Iran). Ostatecznie jednak USA i Rosja doszły do porozumienia w kwestiach rozbrojeniowych podpisując w $2010 \mathrm{r}$. (w $2011 \mathrm{r}$. wszedł w życie) nowy układ START, który przewiduje zmniejszenie przez obie strony liczby strategicznych głowic nuklearnych z 2200 do 1550 . Należy podkreślić, że po zakończeniu zimnej wojny więcej państw zrezygnowało z posiadania broni jądrowej lub wycofało się ze swoich programów atomowych $w$ stosunku do tych, które podjęły działania na rzecz pozyskania BMR. Pomimo że ciagle ponad $90 \%$ broni jądrowej znajduje się na terytorium Rosji i USA, to problem jej proliferacji staje się coraz poważniejszym zagrożeniem dla bezpieczeństwa międzynarodowego z powodu atomowych aspiracji szeregu państw wykazujących tendencje do prowadzenia działań destabilizujących środowisko bezpieczeństwa. Należy zgodzić się z poglądem, że niekontrolowana proliferacja BMR nie oznacza wcale stabilizacji związanej z nuklearnym odstraszaniem, ale zwiększa ryzyko wybuchu konfliktu nuklearnego (Fiedler, 2011: 46-49). W przypadku UE problem BMR jest o tyle istotny, że dwa państwa UE tj. Wielka Brytania i Francja są państwami posiadającymi broń jądrową w rozumieniu układu NPT. Ponadto broń taktyczna USA jest składowana na terytorium niektórych państw członkowskich. W przypadku problematyki rozprzestrzeniania BMR stanowisko PE jest jednoznaczne $i$ bezkompromisowe oraz nastawione na eliminację zagrożeń związanych z występowaniem broni jądrowej. Dowodem na to jest sprzeciw PE odnoszący się do rozwoju przez USA broni jądrowej nowej generacji (tzw. mini bomby jądrowej), jak i wezwanie do działań zapobiegających dalszemu rozprzestrzenianiu pocisków balistycznych o zwiększonym zasiegu i celności poprzez rozwój i rozszerzanie członkostwa w mechanizmach kontroli zbrojeń, takich jak Reżim Kontrolny Technologii Rakietowych (MTCR) i haski kodeks postępowania. W opinii PE priorytety UE w obszarze BMR powinny być następujące (Rezolucja, 2006b):

1) zaangażowanie na szczeblu międzynarodowym promujące wdrażanie strategii UE w sprawie BMR;

2) położenie większego nacisku na inicjatywy rozbrojeniowe oraz na zagadnienia związane z nierozprzestrzenianiem BMR;

3) wzmocnienie układów wielostronnych składających się na system nierozprzestrzeniania;

4) położenie nacisku na nierozprzestrzenianie i zagrożenia związane z wykorzystaniem BMR przez terrorystów;

5) zapewnienie zasobów finansowych potrzebnych na wdrażanie strategii UE w sprawie BMR. 
W przypadku porozumień zawieranych przez UE z państwami trzecimi PE opowiada się za włączeniem do tych umów klauzul dotyczących nierozprzestrzeniania BMR oraz wzywa te państwa, a w szczególności te posiadające broń jądrową do nieudzielania pomocy ani poparcia krajom, które mogą starać się o nabycie tego rodzaju broni. Mając prawo zatwierdzania najważniejszych umów międzynarodowych PE opowiada się za uzależnieniem współpracy z UE od wypełniania przez stronę trzecią postanowień NPT. Ponadto PE postuluje zwiększenie zasobów UE umożliwiających wniesienie istotnego wkładu do reżimu inspekcyjnego ONZ kontrolującego nierozprzestrzenianie BMR. W przypadku Bliskiego Wschodu i obszaru śródziemnomorskiego PE stoi na stanowisku ustanowienia na tym obszarze strefy bez BMR oraz wzywa takie kraje jak Izrael, Indie i Pakistan, aby stały się stronami NPT. Potwierdza również znaczenie ściślejszej współpracy ze Stanami Zjednoczonymi, w celu wzmocnienia międzynarodowego systemu układów i reżimów wymierzonych przeciwko rozprzestrzenianiu BMR, zapewnienia dokładnego wdrażania i przestrzegania postanowień, wspierania nierutynowych inspekcji, jak również uznania, że do zwalczania rozprzestrzeniania BMR mogą być potrzebne inne środki zgodne z prawem międzynarodowym. Opowiada się ponadto za szybkim podpisaniem i ratyfikowaniem CTBT (ibidem). Analizując stanowisko PE w kwestii rozbrojenia nuklearnego należy podkreślić, że organ ten domaga się od potęg jądrowych stopniowego zmniejszania liczby głowic atomowych. Opowiada się ponadto za całkowitym zakazem używania broni chemicznej, biologicznej, a także min przeciwpiechotnych, amunicji kasetowej i amunicji zawierającej zubożony uran. Na uwage zasługuje fakt, że PE sprzeciwiał się pierwotnym planom umieszczenia amerykańskiej tarczy antyrakietowej w Europie, opowiadając się za opracowaniem nowego podejścia w tej kwestii uwzględniającego interesy całej Europy i Rosji. Również zastanawiające jest podejście PE wobec atomowej obecności USA w Europie. W przyjętym stanowisku PE za strategiczny anachronizm uznaje składowanie w Europie taktycznej broni jądrowej, domagając się ograniczenia tego rodzaju broni oraz stopniowego jej usunięcia z terytorium europejskiego. W tej kwestii PE zaleca prowadzenie dialogu z Rosją (Rezolucja, 2010). Należy podkreślić, że UE problemy w kwestii nierozprzestrzeniania BMR stara się rozwiązywać na drodze dyplomatycznej, prowadząc jak najdłużej dialog z państwami łamiącymi zasady NPT. Potwierdzenie tej tezy stanowią relacje UE z Iranem. Program nuklearny tego kraju stanowi jedno z największych wyzwań dla polityki zagranicznej i bezpieczeństwa UE. Chcąc zapobiec akcji militarnej forsowanej przez Izrael i część amerykańskich polityków, UE postawiła w stosunkach z Iranem na dialog dyplomatyczny, powołując europejską formułę negocjacyjną złożoną z trzech największych państw (Niemcy, Wielka Brytania, Francja) znaną pod nazwą EU3 (Klimowicz, 2014: 67). Polityka UE w kwestii irańskiego programu nuklearnego zyskała pełną aprobatę ze strony PE, który w przyjętym stanowisku wyraził poparcie dla starań UE mających na celu rozwiązanie problemu irańskiego na drodze negocjacji dyplomatycznych. Potępiając Iran za niestosowanie się do międzynarodowych zobowiązań w zakresie zawieszenia wszelkiej działalności związanej ze wzbogacaniem i przetwarzaniem materiałów jądrowych, PE odrzucił jednak możliwość podjęcia akcji zbrojnej przeciwko Iranowi. W przyjętym stanowisku wezwał administrację USA oraz pozostałe zaangażowane w sprawę podmioty do zarzucenia skierowanej przeciwko Teheranowi retoryki odwołującej się do rozwiązania siłowego 
i nawołującej do zmiany reżimu w tym państwie. Zdaniem PE znalezienie kompleksowego porozumienia w sprawie irańskiego programu jądrowego nie będzie możliwe bez wielostronnej współpracy zainteresowanych stron, w tym USA, ChRL i Rosji (Rezolucja , 2008). Niechęć Iranu do poddania się całościowej kontroli nad procesem wzbogacania uranu spowodowała, że UE w latach 2010-2012 nałożyła na to państwo sankcje ekonomiczne i polityczne, w tym embargo na eksport ropy naftowej. Sankcje nałożone przez Radę UE dotyczące sektora energii, finansów, transportu i konkretnych osób oraz organizacji spotkały się z aprobatą PE, który w przyjętym stanowisku zastrzegł, aby ukierunkowane one były na założony cel, proporcjonalnie do niego i realizowane z myślą o wywarciu nacisku na represyjny reżim przy minimalizacji negatywnych skutków dla ludności cywilnej (Rezolucja, 2013a). Podsumowując stanowisko PE wobec zasadniczej kwestii WPBiO jaka jest problem rozprzestrzeniania BMR można na podstawie szeregu rezolucji przez ten unijny organ przyjmowanych stwierdzić, że dla PE celem strategicznym jest całkowita likwidacja BMR. Jest to podejście dość kontrowersyjne, gdyż sprzeczne z poglądami rządów państw członkowskich NATO, a zarazem UE, które w koncepcji strategicznej przyjętej w 2010 r. potwierdziły, że odstraszanie Sojuszu opiera się na kombinacji nuklearnych i konwencjonalnych zdolności oraz opowiedziały się za utrzymaniem w przyszłości jego nuklearnego charakteru (Koncepcja, 2011: 207). Podejście to dobrze oddaje jednak dominujące w społeczeństwach europejskich nastroje pacyfistyczne przekładające się na postawę elit zachodnioeuropejskich. Postawy te znajdują szczególny oddźwięk na forum PE, które zdominowane jest przez zasady poprawności politycznej co jeszcze potęguje radykalizm przyjmowanych opinii w dziedzinie rozbrojenia. Ponadto niewiążący charakter wyrażanych przez PE stanowisk wpływa na ich treść, potegując ich rozbrojeniowy wydźwięk. Ponadto PE z zasady sprzeciwia się stosowaniu siły militarnej wobec państw mających problemy z wypełnianiem zobowiązań wynikających z NPT, preferując prowadzenie dialogu dyplomatycznego z tymi państwami oraz postulując konieczność wypracowania porozumienia przy udziale innych uczestników stosunków międzynarodowych tj. zainteresowanych państw i organizacji, zwłaszcza ONZ.

\section{STANOWISKO PARLAMENTU EUROPEJSKIEGO WOBEC TERRORYZMU MIĘDZYNARODOWEGO}

W hierarchii głównych zagrożeń dla bezpieczeństwa UE opisanych w ESB obok proliferacji broni masowego rażenia znajduje się terroryzm. Zagrożenie to zwłaszcza po zakończeniu zimnej wojny przybrało charakter globalny, gdyż do zamachów terrorystycznych dochodzi w różnych miejscach oddalonych od siebie nie tylko pod względem geograficznym, ale również różniących się pod względem kulturowym, politycznym i ekonomicznym. Oznacza to, że zamachy terrorystyczne mogą być przygotowywane i organizowane daleko od rzeczywistego celu ataku, a terroryści są w stanie tworzyć międzynarodowe sieci powiązań (ponadnarodowe grupy posiadające swoje komórki w różnych państwach i planujące zamachy w skali globalnej). Na zjawisko, jakim jest współczesny terroryzm, składa się nie tylko globalny zakres jego występowania, ale również globalny strach i stereotypy towarzyszące temu zjawisku, globalne 
terrorystyczne idee, strategie, taktyki, skutki, jak i przeciwdziałania temu zagrożeniu (Wojciechowski, 2011a: 235-237). Do czynników generujących tak rozumiany terroryzm zalicza się: konflikty etniczne, religijne, ideologiczne, polityczne, negatywne następstwa procesu modernizacji, niesprawiedliwe stosunki społeczne, wrzenie rewolucyjne panujące w społeczeństwach, upadek państw spowodowany słabością władz centralnych (Wojciechowski, 2011 b: 64). Czynniki te szczególnie występują w południowym sassiedztwie UE, co w połączeniu $\mathrm{z}$ brakiem granic wewnętrznych w ramach UE i nieszczelnością jej granic zewnętrznych sprawia, że zagrożenie terrorystyczne w Europie w ostatnich kilkunastu latach znaczaco wzrosło.

Zainteresowanie UE tym zagrożeniem wzrosło szczególnie po zamachach w Nowym Jorku, które wymusiły na organach UE wypracowanie multilateralnego podejścia do zjawiska terroryzmu. Państwa członkowskie UE, chcąc wspólnie walczyć z terroryzmem i chronić swoje bezpieczeństwo, przyjęły w 2005 r. Strategię ws. Zwalczania Terroryzmu opartą na czterech filarach: zapobieganiu, ochronie, ściganiu, reagowaniu. Zakłada ona, że za walkę $\mathrm{z}$ terroryzmem odpowiadają przede wszystkim państwa członkowskie, a rolą UE jest zaproponowanie wartości dodanej w postaci europejskiej współpracy. Również w 2005 r. została przyjęta Strategia UE w sprawie zwalczania radykalizacji postaw i rekrutacji do ugrupowań terrorystycznych, której nadrzędnym celem jest walka z korzeniami terroryzmu przez odcięcie organizacji terrorystycznych od możliwości rekrutacji nowych członków (Szlachter, 2009: 5). Odnosząc się do strategii UE i państw członkowskich oraz stowarzyszonych odnoszących się do przeciwdziałania terroryzmowi międzynarodowemu, PE podkreśla, że muszą się one opierać na zasadzie praworządności i przestrzegania praw podstawowych. Dlatego zewnętrzne działania UE w zakresie przeciwdziałania terroryzmowi powinny w pierwszym rzędzie skupiać się na prewencji, promowaniu dialogu, tolerancji i zrozumienia różnych kultur, cywilizacji, religii. Istotą działań UE i państw członkowskich w zakresie zwalczania terroryzmu powinna być skuteczność, proporcjonalność reakcji do występujących zagrożeń, a przede wszystkim kontrola demokratyczna nad działaniami antyterrorystycznymi, która ma gwarantować, że strategie antyterrorystyczne będą zgodne z prawem pierwotnym UE, a szczególnie z Kartą Praw Podstawowych (Rezolucja, 2013b). Poszanowanie praw podstawowych stanowi więc w opinii PE czynnik o zasadniczym znaczeniu dla powodzenia polityki zwalczania terroryzmu. Dlatego w swoich stanowiskach PE potępiał prowadzone przez USA i realizowane przez CIA programy wydawania osób podejrzanych o terroryzm do państw stosujących tortury, a także programy tajnego przetrzymywania tych osób w państwach trzecich, co skutkowało w wielu przypadkach stosowaniem tortur i okrutnym traktowaniem. W swoich rezolucjach PE wzywał państwa członkowskie UE, w których ludzie byli przetrzymywani w ramach programu CIA w tajnych obiektach na ich terytorium do przeprowadzenia niezależnych i skutecznych śledztw w sprawie łamania praw człowieka i ujawnienia wszelkich niezbędnych informacji w powyższej sprawie. W związku z tym PE sformułował zalecenia skierowane do KE, aby ta zbadała, czy w wyniku współpracy z programem CIA doszło do naruszenia przepisów UE, zwłaszcza tych dotyczących azylu i współpracy sądowej. Ponadto KE powinna: 1) monitorować i wspierać krajowe procesy pociagania sprawców do odpowiedzialności; 2) przyjąć środki mające na celu wzmocnienie zdolności UE do zapobiegania naruszeniom praw człowieka; 3) stworzyć mechanizmy 
pozwalające zadośćuczynić ofiarom procederu naruszania tych praw; 4) ułatwiać i wspierać pomoc prawną i współpracę wymiarów sprawiedliwości w pociąganiu do odpowiedzialności sprawców w państwach członkowskich; 5) przedstawić wnioski w sprawie opracowania ustaleń odnośnie demokratycznego nadzoru nad transgranicznymi działaniami wywiadowczymi w kontekście polityki UE na rzecz przeciwdziałania terroryzmowi. Natomiast w szczegółowych zaleceniach skierowanych do Rady, PE domagał się wydania przez Radę oświadczenia potwierdzającego udział państw członkowskich w programie CIA, a także udzielenia pełnego poparcia procesom ustalania prawdy i rozliczania osób odpowiedzialnych w państwach członkowskich za czyny niezgodne $\mathrm{z}$ prawem (Rezolucja, 2013c). Problemem dostrzeganym przez PE jest sprawa zapobiegania radykalizacji oraz rekrutacji obywateli państw europejskich przez organizacje terrorystyczne. Bezpieczeństwo Europy Zachodniej w ostatnich latach jest szczególnie zagrożone przez rozwój ruchu dżihadystycznego skupiającego skrajne środowiska islamskich radykałów. Uważają oni siebie za awangardę świata muzułmańskiego, opowiadając się za ortodoksyjnie rozumianą koncepcją dżihadu (świętej wojny). Cechą tego ruchu jest jego globalny, ponadnarodowy charakter, który umożliwia muzułmanom z całego świata połączenie wysiłków na rzecz realizacji idei zbrojnej ummy walczącej o przetrwanie społeczności islamskiej (Wejkszner, 2014: 225-226). Pojawienie się postaw radykalnych i fundamentalistycznych w państwach i społecznościach muzułmańskich jest pochodną fiaska procesu przyspieszonej modernizacji i reform społecznych przeprowadzanych przez rządy państw islamskich, a także występującego w tych państwach ubóstwa. Do rażących dysproporcji społeczno-ekonomicznych sprzyjających radykalizacji postaw oraz zwiększających popularność działań terrorystycznych dochodzą również czynniki polityczne takie jak: rewolucja islamska w Iranie, konflikt arabsko-izraelski, wojny w Afganistanie i Iraku (Wojciechowski, 2011b: 67). Dla wzrostu zagrożenia terrorystycznego w Europie ma to istotne znaczenie, gdyż środowiska islamskich fundamentalistów stanowią naturalną bazę rekrutacyjną dla organizacji terrorystycznych.

Określając swoje stanowisko wobec tego problemu, PE wyszedł z założenia, że terroryzm nie może być utożsamiany z żadną konkretną religia, narodowością czy cywilizacją. Według PE przyczyn radykalizacji postaw i popularności organizacji terrorystycznych należy upatrywać w sytuacji panującej w europejskich więzieniach. Przeludnienie zakładów karnych, brak izolacji od innych więźniów osób skazanych za działalność terrorystyczną i wyznających brutalny ekstremizm, brak specjalistycznych szkoleń dla personelu więziennego, a także brak programów pedagogicznych promujących krytyczne myślenie, tolerancję religijną i reintegrację w społeczeństwie więźniów sprawiają że więzienia stają się wylęgarnią postaw radykalnych i miejscem werbunku dla organizacji terrorystycznych. Zdaniem PE warunkiem zapobieżenia tym negatywnym zjawiskom jest zapewnienie przez państwa członkowskie UE takich warunków odbywania kary w więzieniach, które zapewnią poszanowanie praw człowieka i będą zgodne z międzynarodowymi i europejskimi standardami. Kluczową kwestią dla poprawy bezpieczeństwa UE jest również zapobieganie terrorystycznej radykalizacji $w$ internecie. To nowe medium wykorzystywane jest jako platforma służąca eskalacji radykalizacji postaw, gdyż umożliwia szybkie rozprzestrzenianie informacji przesyconych nienawiścią oraz pochwalających terroryzm. Remedium na to zjawisko, PE upa- 
truje w zaostrzeniu kontroli stron internetowych podżegających do nienawiści, usuwaniu wszelkich treści o charakterze ekstremistycznym, zwalczaniu mowy nienawiści, rozpowszechnianiu idei poszanowania praw człowieka i komunikatów dotyczących zapobiegania radykalizacji postaw, a także utworzeniu w ramach Europolu europejskiego centrum ds. walki z terroryzmem i wchodzącej w jego skład jednostki ds. zgłaszania podejrzanych treści w internecie. Zapobieganie radykalizacji postaw nie będzie możliwe w opinii PE bez odpowiedniej edukacji i integracji społecznej. Szkoły powinny propagować niedyskryminacje, tolerancję, prawa człowieka, dialog międzykulturowy, wspierać nauczycieli w aktywnym sprzeciwianiu się wszelkim formom dyskryminacji i rasizmu. Młodzi ludzie muszą mieć świadomość, że różnorodność Europy oraz jej wielokulturowe społeczeństwa są wartością dodaną i dlatego należy przeciwdziałać islamofobii, która przyczynia się do wykluczania muzułmanów ze społeczeństwa, powodując wzrost popularności organizacji ekstremistycznych. Dlatego PE zaleca państwom członkowskim UE przyjmowanie krajowych strategii zwalczania islamofobii w celu rozwiązywania problemu dyskryminacji utrudniającej dostęp do edukacji, zatrudnienia i mieszkań. Ponadto PE opowiada się za wzmocnieniem roli centrum koordynacyjnego Eurojustu, które powinno promować wspólne działania organów sądowych państw UE na rzecz gromadzenia dowodów i w większym stopniu wykorzystywać wspólne zespoły dochodzeniowo-śledcze. Zachęca również UE do prowadzenia dialogów dotyczących bezpieczeństwa i zwalczania terroryzmu z państwami trzecimi szczególnie narażonymi na to zjawisko oraz wzywa Radę UE do wyraźnego potępienia wsparcia finansowego i ideologicznego udzielanego ekstremistycznym ruchom islamistycznym przez rządy i wpływowe osoby w niektórych państwach Zatoki Perskiej (Rezolucja, 2015a). Problemem będącym pochodną wzrostu postaw radykalnych i ekstremistycznych, na który zwraca uwagę PE jest szybki wzrost liczby obywateli UE udających się w strefy konfliktów, aby dołączyć do organizacji terrorystycznych. Ich powrót na terytorium UE stanowi w opinii PE zagrożenie dla bezpieczeństwa UE i życia jej obywateli. Jednakże stosowanie środków prawnych, wyposażanie organów ścigania $w$ narzędzia umożliwiające wykonywanie przez nie swoich obowiązków i wprowadzanie ograniczeń w funkcjonowaniu strefy Schengen nie może być jedynym panaceum na rozwiązanie tego problemu. Poradzenie sobie ze zjawiskiem terroryzmu wymaga w opinii PE opracowania przez UE antyterrorystycznej strategii opartej na wielopłaszczyznowym podejściu, uwzględniającym przyczyny radykalizacji prowadzącej do agresywnego ekstremizmu (brak spójności społecznej i integracji, nietolerancja), analizę propagandy terrorystycznej w internecie, środki zapobiegające rekrutacji do organizacji terrorystycznych i ich finansowaniu. Elementami walki z terroryzmem muszą być również: strategia na rzecz ochrony i wsparcia ofiar i ich rodzin, zwalczanie handlu bronią, ludźmi, walka z praniem pieniędzy, dokładniejsze kontrole na granicach zewnętrznych UE, lepsza wymiana informacji między organami ścigania w państwach członkowskich a agencjami UE, kompleksowa ocena przez Radę UE i KE przyjętych w UE środków zwalczania terroryzmu, harmonizacja w skali UE kryminalizacji przestępstw związanych z zagranicznymi bojownikami, wzmocnienie demokratycznego i sądowego nadzoru nad polityką zwalczania terroryzmu i działaniami służb wywiadowczych, opracowanie strategii współpracy z państwami trzecimi w dziedzinie walki $\mathrm{z}$ terroryzmem przy zapewnieniu przestrzegania międzynarodowych uregulowań doty- 
czących praw człowieka, wykorzystanie przez UE istniejących programów i zdolności w celu zapobiegania i przeciwdziałania radykalizacji w krajach szczególnie dotkniętych zjawiskiem terroryzmu, pogłębienie współpracy z podmiotami społeczeństwa obywatelskiego w państwach trzecich dotkniętych terroryzmem, propagowanie w środowisku międzynarodowym idei dobrych rządów oraz zapobieganie międzynarodowym konfliktom i ich rozwiązywanie (Rezolucja, 2015b). Podsumowując, stanowisko PE wobec kluczowego dla bezpieczeństwa Europy zagrożenia, jakim jest terroryzm można sformułować tezę, że organ ten sprzeciwia się radykalnym projektom (np. kontrola granic wewnętrznych, wydalanie własnych obywateli odpowiedzialnych za akty terrorystyczne, wprowadzenie nadzwyczajnych środków prawnych) mogącym skutecznie przeciwdziałać rozszerzaniu się tego zagrożenia. Według PE remedium na wzrost zagrożenia terrorystycznego powinno być stosowanie miękkich narzędzi oddziaływania takich jak strategie, programy, plany działania, klauzule międzynarodowe, projekty edukacyjne. Analiza dokumentów przyjmowanych przez PE pozwala sformułować pogląd, że większość europosłów z racji wyznawanej orientacji lewicowo-liberalnej spogląda na walkę z terroryzmem przez pryzmat dominujących w Europie Zachodniej zasad poprawności politycznej. Dlatego zdaniem PE walka z terroryzmem powinna polegać przede wszystkim na eliminowaniu jego przyczyn takich jak: wykluczenie, dyskryminacja, nietolerancja, islamofobia. Oznacza to, że PE odrzuca pogląd opisujący zagrożenie terrorystyczne w kontekście starcia radykalnego islamu z cywilizacją europejską opartą na kulturze chrześcijańskiej. Stanowisko to wpisuje się w lansowaną przez UE koncepcję zwalczania terroryzmu koncentrującą się przede wszystkim na prowadzeniu działań ochronnych na własnym terytorium, co oznacza prezentowanie głębokiego sceptycyzmu wobec preferowanych przez USA działań ofensywnych $\mathrm{w}$ wojnie $\mathrm{z}$ terroryzmem, mających na celu również realizację określonych celów geopolitycznych (Grosse, 2010: 42).

Nie ulega wątpliwości, że skuteczność UE w dziedzinie zwalczania terroryzmu międzynarodowego i proliferacji broni masowego rażenia wymaga ścisłej współpracy państw członkowskich. Instrumentem tej współpracy jest przede wszystkim WPBiO, która łączy środki prewencyjne i wojskowe środki reagowania kryzysowego z cywilnymi, dając UE szansę stania się kompleksowym aktorem stosunków międzynarodowych (Zajączkowski, 2009: 50-51). Waga tej polityki dla potwierdzania tożsamości UE na arenie międzynarodowej sprawia, że WPBiO staje się przedmiotem szczególnego zainteresowania PE. Oceniając stanowisko PE wobec głównych zagrożeń dla bezpieczeństwa Unii, które są przedmiotem zainteresowania WPBiO należy zauważyć, że z formalno-traktatowego punktu widzenia PE nie jest pehnoprawnym podmiotem współdecydującym o kształcie tej polityki. Wynika to z faktu, że PE jako instytucja o charakterze ponadnarodowym nie posiada kompetencji decyzyjnych w odniesieniu do zdominowanej przez mechanizmy współpracy międzyrządowej WPBiO stanowiącej integralną część WPZiB. Oznacza to, że w odniesieniu do takich zagadnień wchodzących w zakres WPBiO jak: zwalczanie terroryzmu międzynarodowego i proliferacji broni masowego rażenia rola PE sprowadza się do bycia przede wszystkim in- 
stytucją o charakterze opiniodawczym i konsultacyjnym. Podstawowym instrumentem wyrażania przez PE opinii w powyższych kwestiach są przyjmowane na jego forum rezolucje nieprawodawcze. Mimo że pozbawione są one mocy prawnie wiążącej mają jednak istotne znaczenie polityczne. Zawierają one poglądy PE, które z racji tego, że jest to jedyna instytucja unijna mająca demokratyczną legitymację, która $z$ założenia reprezentuje społeczeństwa Europy muszą być w mniejszym lub większym stopniu uwzględniane przez pozostałe organy UE, jak i państwa członkowskie. PE wyrażając swoje stanowisko wobec kluczowych zagrożeń dla bezpieczeństwa Unii może powoływać się na wolę europejskiej opinii publicznej, zarazem poprzez rezolucje ją kształtując. Pozwala mu to odgrywać w stosunku do Rady UE będącej najważniejszym organem kształtującym politykę Unii wobec terroryzmu międzynarodowego i proliferacji broni masowego rażenia rolę instytucji wpływu politycznego, której znaczenie wykracza daleko poza jej traktatowe kompetencje. Z przyjmowanych przez PE stanowisk wynika, że organ ten w kwestiach rozwiązywania konfliktów i eliminowania zagrożeń dla bezpieczeństwa opowiada się za stosowaniem przede wszystkim środków cywilnych, a nie wojskowych, podkreślając swoje przywiązanie do międzynarodowego multilateralizmu. W jego opiniach zauważalny jest pogląd, że kluczową rolę w zapewnieniu bezpieczeństwa i przeciwdziałaniu takim zagrożeniom jak rozprzestrzenianie broni masowego rażenia czy terroryzm powinny odgrywać wielostronne struktury międzynarodowe na czele z ONZ. Na obecnym poziomie rozwoju WPBiO wdrożenie w życie opinii $\mathrm{PE} w$ powyższych dziedzinach uzależnione jest od decyzji podejmowanych przez organy międzyrządowe UE tj. Radę Europejską i Radę UE. Ażeby PE stał się pełnoprawnym w stosunku do tych organów podmiotem decyzyjnym musiałaby zostać zmaterializowana koncepcja ustanowienia ponadnarodowej unii politycznej, w ramach której możliwe by było prowadzenie polityki zagranicznej i bezpieczeństwa poza instytucjami państwa narodowego.

\section{BIBLIOGRAFIA}

Chodubski A. (2012), Teorie i metody badań europeistycznych, w: Teorie w studiach europejskich. W kierunku nowej agendy badawczej, (red.) J. Ruszkowski, L. Wojnicz, Szczecin-Warszawa.

Fiedler R. (2011), Pesymiści i optymiści. Dwa podejścia wobec problemu proliferacji broni jadrowej po zimnej wojnie, „Przegląd Strategiczny”, nr 2.

Grosse T. G. (2010), Systemowe uwarunkowania slabości polityki zagranicznej UE, „Studia Europejskie", nr 1.

Klimowicz D. (2014), Irański kryzys nuklearny jako test dla unijnej polityki zagranicznej, „Studia Europejskie", nr 2.

Koncepcja Strategiczna NATO z 2010 r. - thumaczenie, http://www.bbn.gov.pl/download/1/.../KoncepcjastrategicznaNATO.pdf (10.03.2013).

Nowe kierunki działań Unii Europejskiej na rzecz zwalczania rozprzestrzeniania broni masowego rażenia $i$ systemów jej przenoszenia (2008), http://register.consilium.europa.eu/doc/srv/ $=\mathrm{PL} \& \mathrm{f}=\mathrm{ST} \% 2017172 \% 202008 \% 20 \mathrm{INIT}(10.09 .2015)$.

Ogonowska A. (2006), Dokumenty i publikacje instytucji i organów Unii Europejskiej, „Zeszyty OIDE", nr 6. 
Rezolucja Parlamentu Europejskiego z 14 kwietnia 2005 r. w sprawie Europejskiej Strategii Bezpieczeństwa (2006a), Dz. U. UE C 33 E, poz. 580.

Rezolucja Parlamentu Europejskiego z 17 listopada 2005 r: w sprawie nierozprzestrzeniania broni masowego razenia: rola Parlamentu Europejskiego (2006b), Dz. U. UE C 280 E, poz. 453.

Rezolucja Parlamentu Europejshiego z 10 marca 2010 r. w sprawie Ukladu o nierozprzestrzenianiu broni jadrowej (2010), Dz. U. UE C 349 E, poz. 77.

Rezolucja Parlamentu Europejskiego z 2 lutego 2012 r. w sprawie Iranu i jego programu jadrowego (2013a), Dz. U. UE C 239 E, poz. 43.

Rezolucja Parlamentu Europejskiego z 14 grudnia 2011 r. w sprawie uninej polityki przeciwdzialania terroryzmowi: najważniejsze osiagnięcia i nadchodzace wyzwania (2013b), Dz. U. UE C 168 E, poz. 45.

Rezolucja Parlamentu Europejskiego z 10 października $2013 \mathrm{r}$. w sprawie rzekomego transportu i nielegalnego przetrzymywania więźniów w krajach europejskich przez CIA (2013c). 2013/2702(RSP), http://www. europarl.europa.eu/sides/getDoc.do?type=TA\&reference=P7$\mathrm{TA}-2013-0418+0+\mathrm{DOC}+\mathrm{XML}+\mathrm{VO} / \mathrm{PL}(20.03 .2016)$.

Rezolucja Parlamentu Europejskiego z 25 listopada 2015 r.w sprawie zapobiegania radykalizacji oraz rekrutacji obywateli europejskich przez organizacje terrorystyczne (2015a). http://www. europarl.europa.eu/sides/getDoc.do?pubRef=-//EP//TEXT+TA+P8-TA-2015$0410+0+\mathrm{DOC}+\mathrm{XML}+\mathrm{VO} / \mathrm{PL}(21.03 .2016)$.

Rezolucja Parlamentu Europejskiego z 31 stycznia 2008 r. w sprawie Iranu (2008), http://www.europarl.europa.eu/sides/getDoc.do?type $=$ TA\&reference $=\mathrm{P} 6-\mathrm{TA}-2008-0031+0+\mathrm{DOC}+\mathrm{XML}+\mathrm{VO} / \mathrm{PL}$ (21.03.2016).

Rezolucja Parlamentu Europejskiego z 11 lutego $2015 \mathrm{r}$ w sprawie środków zwalczania terroryzmu (2015b), http://www.europarl.europa.eu/sides/getDoc.do?type=TA\&reference=P8-TA-2015$0032+0+\mathrm{DOC}+\mathrm{XML}+\mathrm{VO} / \mathrm{PL}(21.03 .2016)$.

Staszczyk A. (2015), Stanowisko Parlamentu Europejskiego wobec Partnerstwa Wschodniego, „Rocznik Integracji Europejskiej”, nr 9 [DOI: 10.14746/rie.2015.9.15].

Szlachter D. (2009), Unia Europejska wobec terroryzmu - aktywność międzynarodowa, http://www.psz.pl/120-unia-europejska/damian-szlachter-unia-europejska-wobec-terroryzmuaktywnosc-miedzynarodowa (21.03.2016).

Wejkszner A. (2014), Ewolucja zagrożenia dżihadystycznego w Europie, „Przegląd Strategiczny”. nr 7 [DOI:10.14746/ps.2014.1.17].

Wojciechowski S. (2011a), Hybrydowy model globalnego terroryzmu, „Przegląd Strategiczny”, nr 2.

Wojciechowski S. (2011b), ,Sieć” przyczyn wspótczesnego terroryzmu - analiza czynników, mechanizmów i modeli, „Przegląd Politologiczny”, nr 3.

Zajączkowski K. (2009), Unia Europejska jako aktor globalny - aspekty polityczno-obronne, „Studia Europejskie", nr 1.

\section{STRESZCZENIE}

Artykuł przedstawia stanowisko Parlamentu Europejskiego (PE) wobec kluczowych zagrożeń dla bezpieczeństwa UE, a zwłaszcza problemu proliferacji broni masowego rażenia i zjawiska terroryzmu międzynarodowego. Przeciwdziałanie tym zagrożeniom należy przede wszystkim do kompetencji państw członkowskich i międzyrządowych organów UE. Wynika to z faktu, że kwestie te wchodzą w zakres Wspólnej Polityki Zagranicznej i Bezpieczeństwa UE, w ramach której dominują międzyrządowe mechanizmy współpracy. W konsekwencji, rola PE 
w kształtowaniu polityki UE w kwestii przeciwdziałania proliferacji broni masowego rażenia i terroryzmu międzynarodowego jest ograniczona i sprowadza się przede wszystkim do wyrażania zawartych w rezolucjach niewiążących opinii. Jednakże przyjmowane przez PE rezolucje w tych kwestiach - mimo że nie wiążą pod względem prawnym - mają swoją istotną wagę polityczną i pozwalają PE, w przeciwieństwie do innych instytucji unijnych, wyrazić swoje stanowisko w sposób jednoznaczny i wyrazisty. Wynika to $z$ faktu bycia przez PE jedyną ponadnarodową instytucją unijną mającą demokratyczną legitymację i mogącą sobie rościć prawo do sprawowania parlamentarnej kontroli nad polityką UE w dziedzinie przeciwdziałania kluczowym dla bezpieczeństwa europejskiego zagrożeniom. Jest to widoczne zwłaszcza w obszarze walki z terroryzmem, który jest również przedmiotem zainteresowania wykorzystującej mechanizmy współpracy ponadnarodowej przestrzeni wolności, bezpieczeństwa i sprawiedliwości.

Slowa kluczowe: Parlament Europejski, Unia Europejska, terroryzm, proliferacja, broń masowego rażenia

\title{
THE EUROPEAN PARLIAMENT TOWARDS THE PROLIFERATION OF WEAPONS OF MASS DESTRUCTION AND TERRORISM
}

\begin{abstract}
The paper presents the stance of the European Parliament (EP) on the gravest threats to the security of the EU, in particular, the proliferation of weapons of mass destruction and the issue of international terrorism. Prevention of these threats lies predominantly within the competence of EU member states and its intergovernmental bodies. Such situation is implied by the fact that these issues fall within the scope of EU's Common Foreign and Security Policy (CFSP) within which intergovernmental collaboration mechanisms play a dominant role. This means that the EP's role in the shaping of EU's policy on the prevention of weapons of mass destruction proliferation and international terrorism is limited and basically confined to the expression of non-binding opinions in its resolutions. However, relevant resolutions passed by the EP, though not binding in legal terms, have political significance and allow the EP, in contrast to other EU's institutions, to articulate its position in an unequivocal and clear way. This is possible since the EP is the only supranational EU institution that has democratic legitimacy and can claim the right to exercise parliamentary control over the EU's policy with respect to the prevention of the gravest threats to European security. This is particularly vivid as it comes to the fight against terrorism which is also the subject of interest for the common space of freedom, security and justice which employs intragovernmental collaboration mechanisms.
\end{abstract}

Key words: European Parliament, European Union, terrorism, proliferation, weapons of mass destruction 